\title{
Response of Plant Nutrients on Soil Fertility, Productivity and Profitability of Rice (Oryza sativa) -Chickpea (Cicer arietinum) Cropping System in Chhattisgarh Plains
}

\author{
C.K. Chandrakar ${ }^{1 *}$, M.C. Bhambri ${ }^{2}$, G.P. Pali ${ }^{2}$, Sunil Kumar ${ }^{2}$, A. Jangde ${ }^{1}$, \\ K.K. Pandey ${ }^{1}$ and Sanjeev Singh ${ }^{3}$
}

${ }^{1}$ S. K. College of Agriculture and Research Station, Kawardha Kabirdham (C.G.), India

${ }^{2}$ College of Agriculture, IGKV, Raipur (C.G.), India

${ }^{3}$ AICRP-IFS project at OFR centre, S.K.C.A.R.S., Kawardha, Kabirdham (C.G.), India

*Corresponding author

\section{A B S T R A C T}

\begin{tabular}{|l|}
\hline Key w or d s \\
Rice-chickpea \\
cropping system, \\
Nutrient response, \\
Productivity, Soil \\
fertility, Economics. \\
\hline Article Info \\
\hline Accepted: \\
15 March 2017 \\
Available Online: \\
10 April 2017 \\
\hline
\end{tabular}

\begin{abstract}
A field experiment was conducted to study the on farm crop response to plant nutrients in pre dominant cropping system i.e. rice, (Oryza sativa) - chickpea (Cicer arietinum) and their impact on productivity, soil fertility and economics at Kabirdham district of Chhattisgarh state during 2013-14 and 2014-15. The results revealed that application of $100 \mathrm{~kg} \mathrm{~N}, 60 \mathrm{~kg} \mathrm{P}_{2} \mathrm{O}_{5}, 40 \mathrm{~kg} \mathrm{~K}_{2} \mathrm{O}$ and $20 \mathrm{~kg} \mathrm{ZnSO}_{4}$ /ha to rice and $20 \mathrm{~kg} \mathrm{~N}, 50 \mathrm{~kg} \mathrm{P}_{2} \mathrm{O}_{5}, 20$ $\mathrm{kg} \mathrm{K}_{2} \mathrm{O}$ /ha to chickpea recorded significantly higher grain and straw/ haulm yields. Rice equivalent yield (87.72 q/ha), net returns (Rs 74,391), benefit cost ratio (2.74) and total NPK uptake by rice-chickpea cropping system $(409.89 \mathrm{~kg} / \mathrm{ha})$ were recorded over rest of the treatments. This treatment also recorded the maximum production efficiency $(39.87 \mathrm{~kg} /$ ha/day). Response studies indicated that maximum response was noted with NPK in Rice $(15.9 \mathrm{~kg} / \mathrm{kg})$ and $\mathrm{N}$ in chickpea $(15.8 \mathrm{~kg} / \mathrm{kg})$.
\end{abstract}

\section{Introduction}

Rice-chickpea cropping sequence is one of the predominant cereals-legume cropping systems being followed in Chhattisgarh as well as in India and occupies considerable geographical distribution. Chhattisgarh plain zone has been blessed with vast tract of area where in farmers are often growing rice and chickpea in sequence. Rice crop is popular in Chhattisgarh due to its versatile characteristics of suitability and adaptability with good market price. Chickpea is preferred after harvest of rice as the crop is the paramount source of protein in predominantly vegetarian diet. Besides this, crop supplies nutritious fodder, feed and it specially fortifies soil through biological nitrogen fixation which is economically sound and environmentally acceptable thereby sustaining the productivity of the cropping system.

The productivity of rice and chickpea of Chhattisgarh are lower than national productivity might be due to low and imbalanced applications of nutrients by the farmers of Chhattisgarh. The continuous use of under and less amount of nutrients to soil erodes the nutrient base and affects the 
productivity (Gangawar et al., 2014). In the recent years, deficiency of micronutrient particularly $\mathrm{Zn}$, is also a factor for decline in the productivity of the system (Hiremath et al., 2015).

Intensive cultivation and growing exhaustive crops have made the soil deficient in macro as well as in micronutrients. The success of any cropping system depends upon the appropriate management of resources including balanced use of manures and fertilizers. The cultivation of legumes has made radical improvement in the farming community (Vidyavathi et al., 2011). Among the various agro-techniques, fertilizer is the single most important input in modern agriculture to raise the crop productivity. To get maximum returns, fertilizers must be applied in a well balanced ratio, leading to their efficient utilization. Though information on nutrient management in individual crops is abundantly available, but the system-based information is meager. Moreover, single nutrient approach has been replaced by multinutrient so as to boost up crop productivity and nutrient use efficiency. Besides, nutrient management in cropping system is more efficient and judicious than individual crop, as succeeding crops take care of the residual effect of nutrients. The present experiment was, therefore, undertaken to study the "On farm crop response to plant nutrients in terms of productivity, soil fertility, nutrient uptake, production efficiency as well as net monetary returns of rice (Oryza sativa)-chickpea (Cicer arietinum) cropping system

\section{Materials and Methods}

Field experiments were conducted during kharif and rabi seasons of 2013-14 and 201415 on farmers' fields in Khandsara, Heerapur and Chorbhhatti villages of Kawardha block and Chilamkhodra, Saliha and Shingarpur village of Sahaspur Lohara block of
Kabirdham district in plain zone of Chhattisgarh. The physical and chemical characteristics of soils for all the sites are given in table 1 .

The experiment comprised of seven treatments viz. control, N, NP, NK, NPK, $\mathrm{NPK}+\mathrm{ZnSO}_{4}$ and farmers' practice was applied to rice and chickpea cropping system. The experiment was conducted in randomized block design with 24 replications. Rice cultivar MTU 1010 and chickpea cultivar Vaibhav were grown. The recommended dose of $\mathrm{N}: \mathrm{P}_{2} \mathrm{O}_{5}: \mathrm{K}_{2} \mathrm{O}: \mathrm{ZnSO}_{4}: 100: 60: 40: 20 \mathrm{~kg} / \mathrm{ha}$ and 20:50:20:0 kg/ha for rice and chickpea respectively was applied. Whereas, in farmer's practices 50:30:20:0 $\mathrm{kg} / \mathrm{ha}$ and 18:48:0:0 kg/ha N: $\mathrm{P}_{2} \mathrm{O}_{5}: \mathrm{K}_{2} \mathrm{O}: \mathrm{ZnSO}_{4}$ were applied in rice and chickpea crops respectively. Half of the nitrogen and full doses of $\mathrm{P}$ and $\mathrm{K}$ were applied at the time of transplanting of rice and remaining $\mathrm{N}$ was applied after 30 DAT. Entire fertilizer was applied at the time of sowing as a basal dose in chickpea. Nitrogen, phosphorus and potassium were applied through Urea, Single super phosphate and Muriate of potash, respectively. Besides, both crops were raised with recommended package of practices.

Both the crops were evaluated in terms of total system productivity, net returns and benefit: cost ratio. On system basis, chickpea seed yield was converted into rice grain equivalent yield (REY) taking into account the prices of both the crops during the respective years.

The data of both the years were pooled and analyzed as per standard procedure. The plant samples were analyzed for $\mathrm{N}, \mathrm{P}$ and $\mathrm{K}$ concentration in grain and straw and total $\mathrm{N}$, $\mathrm{P}$ and $\mathrm{K}$ uptake was calculated by multiplying the respective nutrient concentrations with the yield. Production efficiency ( $\mathrm{kg} / \mathrm{ha} / \mathrm{day})$ was calculated by dividing the in rice - grain 
equivalent yield with total duration of the cropping system. Response of rice and chickpea to $\mathrm{N}, \mathrm{P}$ and $\mathrm{K}$ was calculated by using the following formulae (Gangwar et al., 2014):

Response of $N(\mathrm{~kg} / \mathrm{kg})=\frac{Y_{n}-Y_{\text {oont }}}{N}$

Where, $\mathrm{Y}_{\mathrm{n}}=$ Grain yield under $\mathrm{N}$ treated plot $(\mathrm{kg} / \mathrm{ha})$

$\mathrm{Y}_{\text {cont }}=$ Grain yield under control $(\mathrm{kg} / \mathrm{ha})$

$\mathrm{N}=$ Amount of nitrogen applied $(\mathrm{kg} / \mathrm{ha})$

Response of $P(\mathrm{~kg} / \mathrm{kg})=\frac{Y_{N P K}-Y_{N K}+Y_{N}}{2 P}$
Where,
$Y_{\mathrm{NPK}}=$ Grain yield under NPK treated plot (kg/ ha)

$\mathrm{Y}_{\mathrm{NK}}=$ Grain yield under NK treated plot $(\mathrm{kg} /$ ha)

$\mathrm{Y}_{\mathrm{NP}}=$ Grain yield under NP treated plot (kg/ha)

$\mathrm{P}=$ Amount of phosphorus applied $(\mathrm{kg} / \mathrm{ha})$

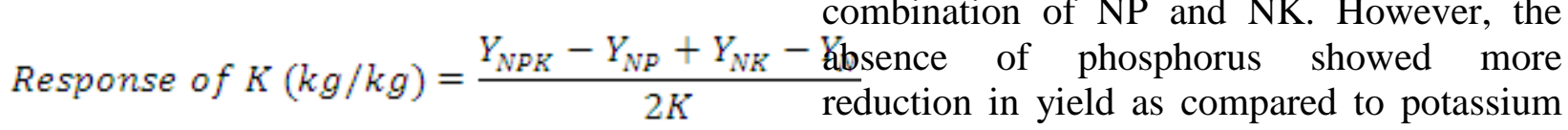

Where,

$\mathrm{K}=$ Amount of potassium applied $(\mathrm{kg} / \mathrm{ha})$.

Correlation Coefficient has been calculated for the straw and yield relation and Regression equation has been used as a prediction equation. Histograms are used for the year wise comparative study.

\section{Results and Discussion}

\section{Productivity}

Application of balance doses of all the three major nutrients $\mathrm{N}, \mathrm{P}_{2} \mathrm{O}_{5}, \mathrm{~K}_{2} \mathrm{O}$ and $\mathrm{ZnSO}_{4}$ at recommended rates to rice and recommended dose of $\mathrm{N}, \mathrm{P}_{2} \mathrm{O}_{5}, \mathrm{~K}_{2} \mathrm{O}$ in chickpea crops resulted in significantly higher grain/seed yields of rice and chickpea during both the years as well as in pooled analysis.

The per cent increase in mean grain yield of rice due to application of $\mathrm{NPK}+\mathrm{ZnSO} 4$, NPK, NK, NP, N and farmer practice (FP) were 174, 166, 72, 126, 44 and 88 per cent respectively over control. The respective increase in mean seed yield of chickpea was 257, 228, 113, 165, 67 and 159 per cent respectively over control (Table 2 ).

The higher increase in grain and seed yield of - Yice and chickpea under $\mathrm{NPK}+\mathrm{ZnSO}_{4}$ and NPK treatments was due to balanced supply of plant nutrients, which increased the protoplasmic constituents and accelerated the process of cell division and elongation which ultimately reflected in increased grain and straw yields. The data also showed that absence of any major nutrient resulted in yield reduction in both the crops. The reduction in yield of rice and chickpea was more when only nitrogen was applied as compared to combination of NP and NK. However, the due to high available potassium in soil. Among the nutrient combinations $\mathrm{NPK}+\mathrm{ZnSO}_{4}$ application was found significantly superior to all other treatments in both the crops. The results are in agreement with the findings of Hite et al., (2007) and Jain et al., (2012).

Correlation Coefficient between grain and straw for 2013, 2014 and Pooled (2013+2014) found significant and near to $1 \mathrm{viz} .0 .99,0.99$ and 0.99 , respectively for the rice crop. Same result for the seed and stover on chickpea crop for 2013, 2014 and pooled data $(2013+2014)$ have been found 0.96, 0.99 and 0.95 respectively has shown in figure 1 . Histogram made for the comparative on 2013, 2014 and pooled data for all the treatments. 
Four equations have been drawn on the basis of pooled yield and pooled NPK consumption. All models are significant at $1 \%$ level. On the basis of Adj $\mathrm{R}^{2}$ models are best fit (Table-3).

\section{System productivity, production efficiency and economics}

The highest system productivity (87.72 q/ha) in terms of rice-grain equivalent yield (RGEY) and production efficiency $(39.87 \mathrm{~kg} /$ ha/ day) were obtained with the application of
$100 \mathrm{~kg} \mathrm{~N}, 60 \mathrm{~kg} \mathrm{P}_{2} \mathrm{O}_{5}, 40 \mathrm{~kg} \mathrm{~K}{ }_{2} \mathrm{O}, 20 \mathrm{~kg}$ $\mathrm{ZnSO}_{4}$ to rice and $20 \mathrm{~kg} \mathrm{~N}, 50 \mathrm{~kg} \mathrm{P}_{2} \mathrm{O}_{5} 20 \mathrm{~kg}$ $\mathrm{K}_{2} \mathrm{O}$ to chickpea on pooled basis (Table 3 ). This is due to application of balanced and recommended dose of fertilizers on ricechickpea cropping system causes higher production in both crops which increase the efficiency of production. The lowest values of system productivity $(30.01 \mathrm{q} / \mathrm{ha})$ and production efficiency (13.4) was recorded under control due to lower yield of both the crops grown in sequence (Table 4), similar results was found by (Hiremath et al., 2015).

Table.1 Average initial physico-chemical properties of soil at different sites (Average of both years)

\begin{tabular}{|c|c|}
\hline Physico-chemical properties of soil & Values \\
\hline Textural class & Clay -clay loam \\
\hline $\mathrm{pH}$ & 7.2 \\
\hline $\mathrm{OC}(\%)$ & 0.6 \\
\hline Available $\mathrm{N}(\mathrm{Kg} / \mathrm{ha})$ & 256.4 \\
\hline Available $\mathrm{P}(\mathrm{Kg} / \mathrm{ha})$ & 12.2 \\
\hline Available $\mathrm{K}(\mathrm{Kg} / \mathrm{ha})$ & 301.4 \\
\hline $\mathrm{E} \mathrm{C}(\mathrm{ds} / \mathrm{m})$ & 0.18 \\
\hline
\end{tabular}

Table.2 Effect of NPK fertilization on grain and straw/stover yield of Rice-Chickpea (pooled data of two years)

\begin{tabular}{|c|c|c|c|c|c|c|c|c|c|c|c|c|}
\hline \multirow[t]{3}{*}{ Treatment } & \multicolumn{6}{|c|}{ Grain/seed yield q/ha } & \multicolumn{6}{|c|}{ Straw/stover yield (q/ha) } \\
\hline & \multicolumn{3}{|c|}{ Rice } & \multicolumn{3}{|c|}{ Chickpea } & \multicolumn{3}{|c|}{ Rice } & \multicolumn{3}{|c|}{ Chickpea } \\
\hline & 2013 & 2014 & Pooled & 2013 & 2014 & Pooled & 2013 & 2014 & Pooled & 2013 & 2014 & Pooled \\
\hline $\mathrm{T}_{1}$-control & 19.74 & 18.32 & 19.03 & 5.38 & 4.31 & 4.84 & 30.17 & 24.42 & 27.30 & 3.42 & 3.05 & 3.24 \\
\hline $\mathrm{T}_{2}-\mathrm{N}$ & 27.77 & 27.32 & 27.54 & 8.77 & 7.22 & 7.99 & 39.98 & 37.98 & 38.98 & 7.94 & 8.81 & 8.38 \\
\hline $\mathrm{T}_{3}-\mathrm{NP}$ & 44.0 & 42.2 & 43.1 & 14.08 & 11.45 & 12.76 & 62.75 & 54.30 & 58.53 & 12.33 & 13.29 & 12.81 \\
\hline $\mathrm{T}_{4}-\mathrm{NK}$ & 32.56 & 33.14 & 32.85 & 10.78 & 9.2 & 9.99 & 42.46 & 46.72 & 44.59 & 9.85 & 10.75 & 10.30 \\
\hline $\mathrm{T}_{5}-\mathrm{NPK}$ & 51.91 & 49.23 & 50.57 & 14.52 & 14.13 & 14.32 & 68.74 & 69.86 & 69.30 & 16.59 & 18.97 & 17.78 \\
\hline $\begin{array}{l}\mathrm{T}_{6^{-}} \\
\mathrm{NPK}+\mathrm{ZnSO}_{4}\end{array}$ & 53.22 & 51.18 & 52.2 & 15.8 & 15.04 & 15.42 & 72.47 & 72.02 & 72.25 & 17.13 & 19.34 & 18.24 \\
\hline $\begin{array}{l}\mathrm{T}_{7-} \text { Farmers } \\
\text { practice }\end{array}$ & 35.94 & 35.98 & 35.96 & 11.13 & 11.2 & 11.16 & 48.48 & 51.03 & 49.76 & 12.97 & 13.05 & 13.01 \\
\hline SEm +_ & 0.6 & 0.36 & 0.48 & 0.11 & 0.22 & 0.16 & 0.51 & 0.57 & 0.54 & 0.04 & \begin{tabular}{|l|l|} 
& 0.08 \\
\end{tabular} & 0.06 \\
\hline $\begin{array}{ll}\mathrm{C} & \mathrm{D} \\
(\mathrm{P}=0.05)\end{array}$ & 1.18 & \begin{tabular}{|l|l}
0.71 \\
\end{tabular} & 0.945 & 0.22 & 0.43 & 0.32 & 1.43 & 1.12 & 1.28 & 0.11 & \begin{tabular}{|l|l|}
0.17 \\
\end{tabular} & 0.14 \\
\hline
\end{tabular}


Table.3 Prediction equation of grain and straw

\begin{tabular}{|l|l|l|l|}
\hline Particulars & Prediction Equation & Adj $\mathbf{R}^{\mathbf{2}}$ & $\begin{array}{l}\text { Significance of the } \\
\text { Model }\end{array}$ \\
\hline Pooled grain rice & $06.45+0.35 \mathrm{~N}+1.06 \mathrm{P}+0.08 \mathrm{~K}$ & 0.99 & 0.0001 \\
\hline Pooled straw rice & $01.99+0.30 \mathrm{~N}+0.48 \mathrm{P}+0.01 \mathrm{~K}$ & 0.92 & 0.0127 \\
\hline Pooled seed chickpea & $15.60+0.65 \mathrm{~N}+1.83 \mathrm{P}+0.67 \mathrm{~K}$ & 0.97 & 0.0035 \\
\hline $\begin{array}{l}\text { Pooled Stover } \\
\text { chickpea }\end{array}$ & $-1.57+0.10 \mathrm{~N}+0.02 \mathrm{P}+0.02 \mathrm{~K}$ & 0.96 & 0.0043 \\
\hline
\end{tabular}

Table.4 Effect of NPK fertilization on Rice Grain Equivalent Yield (RGEY), economics and production efficiency of rice-chickpea cropping system

\begin{tabular}{|c|c|c|c|c|c|c|c|c|}
\hline \multirow[b]{2}{*}{ Treatment } & \multirow{2}{*}{$\begin{array}{l}\text { RGEY } \\
(q / h a)\end{array}$} & \multicolumn{3}{|c|}{ Net Returns } & \multicolumn{3}{|c|}{ B:C Ratio } & \multirow{2}{*}{$\begin{array}{l}\text { Production } \\
\text { Efficiency } \\
\text { kg/ha/day }\end{array}$} \\
\hline & & $\begin{array}{l}\text { Rice } \\
\text { Rs/ha }\end{array}$ & $\begin{array}{c}\text { Chickpea } \\
\text { Rs/ha }\end{array}$ & Total & Rice & Chickpea & Total & \\
\hline $\mathrm{T}_{1}$-control & 30.01 & 4,534 & 5,187 & 9,721 & 1.21 & 1.56 & 1.38 & 13.64 \\
\hline $\mathrm{T}_{2}-\mathrm{N}$ & 45.47 & 14,393 & 13,775 & 28,168 & 1.63 & 2.36 & 2.13 & 20.67 \\
\hline $\mathrm{T}_{3}-\mathrm{NP}$ & 73.55 & 35,235 & 24,019 & 59,254 & 2.39 & 2.74 & 2.56 & 33.43 \\
\hline $\mathrm{T}_{4}-\mathrm{NK}$ & 55.44 & 20,926 & 18,314 & 39,240 & 1.98 & 2.60 & 2.29 & 25.20 \\
\hline $\mathrm{T}_{5}-\mathrm{NPK}$ & 83.48 & 42,291 & 27,946 & 70,237 & 2.58 & 2.82 & 2.70 & 37.95 \\
\hline $\begin{array}{l}\mathrm{T}_{6^{-}} \\
\mathrm{NPK}+\mathrm{ZnSO}_{4}\end{array}$ & 87.72 & 44,605 & 29,786 & 74,391 & 2.74 & 2.87 & 2.81 & 39.87 \\
\hline $\begin{array}{l}\mathrm{T}_{7} \text { - Farmers } \\
\text { practice }\end{array}$ & 61.05 & 24,775 & 20,974 & 45,749 & 2.24 & 2.72 & 2.48 & 27.75 \\
\hline $\mathrm{SEm}+$ & 0.37 & 359 & 277 & & 0.046 & 0.025 & & \\
\hline C.D. $(\mathrm{P}=0.05)$ & 1.04 & 1005 & 777 & & 0.129 & 0.071 & & \\
\hline
\end{tabular}

Table.5Nutrient response $(\mathrm{kg} / \mathrm{kg})$ of rice-chickpea cropping system (pooled of both years)

\begin{tabular}{|l|c|c|}
\hline Treatment & $\begin{array}{l}\text { Response of nutrient (kg/kg) } \\
\text { over control in rice }\end{array}$ & $\begin{array}{l}\text { Response of nutrient (kg/kg) } \\
\text { over control in chickpea }\end{array}$ \\
\hline $\mathrm{T}_{1}$-control & - & - \\
\hline $\mathrm{T}_{2}-\mathrm{N}$ & 8.5 & $\mathbf{1 5 . 8}$ \\
\hline $\mathrm{T}_{3}-\mathrm{NP}$ & 15.0 & 11.3 \\
\hline $\mathrm{T}_{4}-\mathrm{NK}$ & 9.9 & 12.9 \\
\hline $\mathrm{T}_{5}-\mathrm{NPK}$ & $\mathbf{1 5 . 9}$ & 10.5 \\
\hline $\mathrm{T}_{6}-\mathrm{NPK}+\mathrm{ZnSO}$ & 15.1 & 11.8 \\
\hline $\mathrm{T}_{7}-\mathrm{Farmers} \mathrm{practice}$ & 14.1 & 9.9 \\
\hline
\end{tabular}


Fig.1 Grain straw relationship as influenced by different nutrient management practices of rice-chickpea cropping system

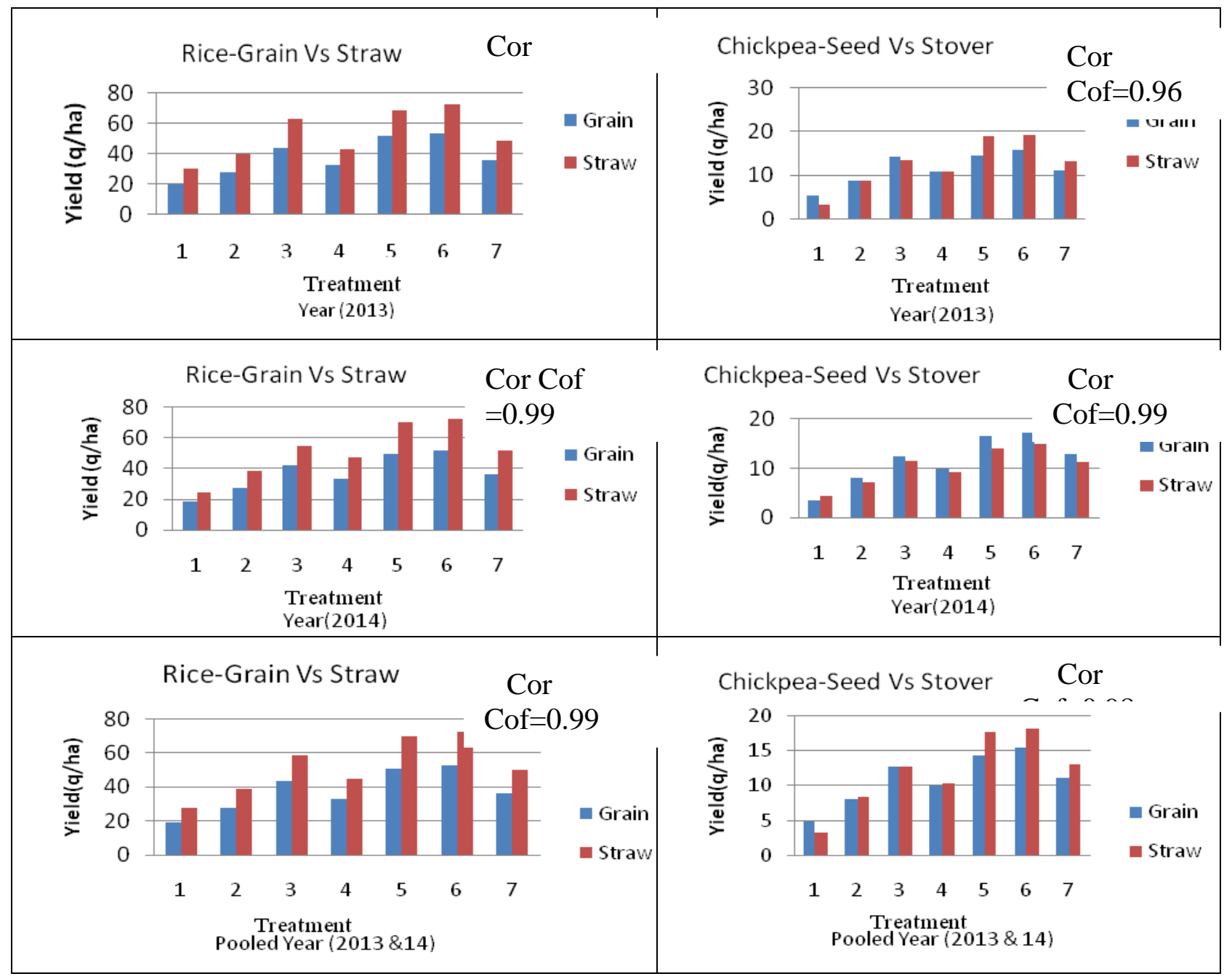

Fig.2 Per cent increment of NPK uptake over control as influenced by different nutrient management practices of rice-chickpea cropping system

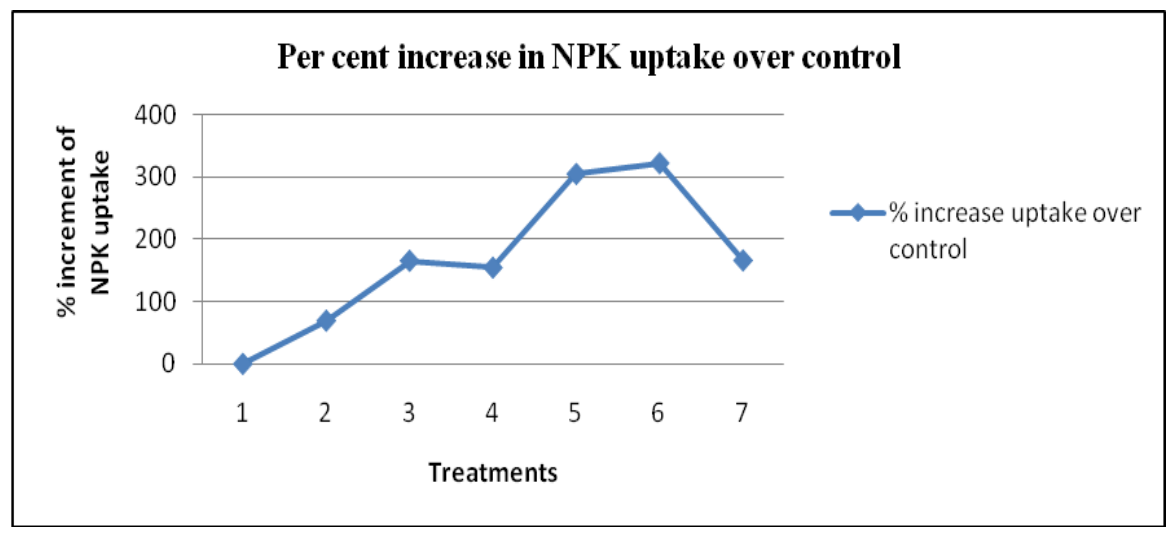


Table-6 Effect of NPK fertilization on nutrient uptake by rice -chickpea cropping system (kg/ha) (pooled data of two years)

\begin{tabular}{|c|c|c|c|c|c|c|c|c|c|c|c|c|c|c|c|c|c|}
\hline \multirow[t]{2}{*}{ Treatment } & \multicolumn{3}{|c|}{$\begin{array}{l}\text { Nutrient uptake by } \\
\text { rice grain }(\mathrm{kg} / \mathrm{ha}) \\
\text { pooled data of two } \\
\text { years }\end{array}$} & \multicolumn{3}{|c|}{$\begin{array}{l}\text { Nutrient uptake by } \\
\text { rice straw (kg/ha) } \\
\text { pooled data of two } \\
\text { years }\end{array}$} & \multicolumn{3}{|c|}{$\begin{array}{l}\text { Nutrient uptake by } \\
\text { Chickpea seed } \\
\text { (kg/ha) pooled data } \\
\text { of two years }\end{array}$} & \multicolumn{3}{|c|}{$\begin{array}{l}\text { Nutrient uptake by } \\
\text { Chickpea stover } \\
\text { (kg/ha) pooled data } \\
\text { of two years }\end{array}$} & \multicolumn{3}{|c|}{$\begin{array}{l}\text { Total nutrient } \\
\text { uptake by rice- } \\
\text { chickpea system }\end{array}$} & \multirow[t]{2}{*}{$\begin{array}{l}\text { Total } \\
\text { uptake } \\
\text { NPK }\end{array}$} & \multirow{2}{*}{$\begin{array}{l}\% \\
\text { increase } \\
\text { in NPK } \\
\text { uptake } \\
\text { over } \\
\text { control }\end{array}$} \\
\hline & $\mathrm{N}$ & $\mathrm{P}$ & $\mathrm{K}$ & $\mathrm{N}$ & $\mathrm{P}$ & $\mathrm{K}$ & $\mathrm{N}$ & $\mathrm{P}$ & $\mathrm{K}$ & $\mathrm{N}$ & $\mathrm{P}$ & $\mathrm{K}$ & $\mathrm{N}$ & $\mathrm{P}$ & $\mathrm{K}$ & & \\
\hline $\mathrm{T}_{1}-\mathrm{cc}$ & 3.15 & 95 & 5.69 & 9.79 & 0.86 & 29.85 & 11.6 & 1.35 & 1.97 & 4.09 & 1.62 & 3.26 & 48.6 & 7.8 & 40.8 & 97.2 & - \\
\hline $\mathrm{T}_{2}-\mathrm{N}$ & 39.81 & 5.75 & 8.97 & 18.49 & 1.74 & 46.72 & 22.37 & 2.39 & 3.41 & 6.81 & 2.57 & 5.4 & 87.5 & 12.5 & 64.5 & 164.4 & 69.13 \\
\hline $\mathrm{T}_{3}-\mathrm{NP}$ & 61.62 & 12.65 & 13.96 & 26.51 & 4.14 & 67.81 & 35.7 & 6.47 & 5.61 & 10.22 & 4.73 & 8.17 & 134.1 & 28.0 & 95.6 & 257.6 & 165.02 \\
\hline $\mathrm{T}_{4}-\mathrm{NK}$ & 48.41 & 7.06 & 19.12 & 21.58 & 2.27 & 90.42 & 28.58 & 3.09 & 5.63 & 8.63 & 3.48 & 8.74 & 107.2 & 15.9 & 123.9 & 247.0 & 154.11 \\
\hline $\mathrm{T}_{5}-\mathrm{NPK}$ & 72.03 & 14.96 & 29.02 & 34.01 & 5.49 & 137.62 & 46.35 & 8.14 & 8.8 & 14.69 & 6.79 & 14.79 & 167.1 & 35.4 & 2 & 392.7 & 304.0 \\
\hline $\begin{array}{l}\mathrm{T}_{6^{-}} \\
\mathrm{NPK}+\mathrm{ZnSO}_{4}\end{array}$ & 74.95 & 15.75 & 30.32 & 34.67 & 5.7 & 142.79 & 47.57 & 8.35 & 12.74 & 15.07 & 7.02 & 15.01 & 172.3 & 36.8 & 200.9 & 409.9 & 321.17 \\
\hline $\begin{array}{l}\mathrm{T}_{7} \text { - Farmers } \\
\text { practice }\end{array}$ & 48.12 & 9.41 & 17.88 & 21.38 & 2.84 & 90.38 & 34.52 & 5.86 & 5.45 & 10.21 & 4.35 & 7.84 & 114.2 & 22.5 & 121.6 & 258.2 & 165.63 \\
\hline $\mathrm{SEm}+$ & 0.54 & 0.18 & 0.27 & 0.34 & 0.11 & 1.31 & 0.75 & 0.1 & 1.26 & 0.21 & 0.09 & 0.17 & - & - & - & - & - \\
\hline C.D. $(\mathrm{P}=0.05)$ & 1.06 & 0.35 & $\mathbf{0 . 5 3}$ & 0.67 & 0.22 & 2.57 & 1.04 & 0.2 & 2.47 & 0.41 & 0.18 & 0.33 & - & - & - & - & - \\
\hline
\end{tabular}


Table-7 Soil fertility status at the end of cropping system (pooled of both years)

\begin{tabular}{|l|c|c|c|}
\hline Treatment & Available N (kg/ha) & Available P $\mathbf{~ k g / h a ) ~}$ & Available K $\mathbf{~ k g / h a ) ~}$ \\
\hline $\mathrm{T}_{1}$-control & 218.8 & 9.90 & 301.62 \\
\hline $\mathrm{T}_{2}-\mathrm{N}$ & 266.3 & 10.37 & 307.85 \\
\hline $\mathrm{T}_{3}-\mathrm{NP}$ & 267.2 & 16.90 & 311.59 \\
\hline $\mathrm{T}_{4}-\mathrm{NK}$ & 269.09 & 10.43 & 351.21 \\
\hline $\mathrm{T}_{5}-\mathrm{NPK}$ & 270.35 & 18.79 & 351.56 \\
\hline $\mathrm{T}_{6}-\mathrm{NPK}+\mathrm{ZnSO}_{4}$ & 271.57 & 19.14 & 353.94 \\
\hline $\begin{array}{l}\mathrm{T}_{7}-\text { Farmers } \\
\text { practice }\end{array}$ & 244.14 & 14.27 & 336.47 \\
\hline $\mathrm{SEm}+-$ & 0.77 & 0.13 & 1.87 \\
\hline C.D.(P=0.05) & 2.17 & 0.36 & 5.25 \\
\hline
\end{tabular}

$\mathrm{NPK}+\mathrm{ZnSO}_{4}$ recorded the highest system net returns (Rs. 74,391/ ha) and benefit : cost ratio (2.81) from rice-chickpea cropping system which was significantly superior to rest of the treatments. These findings are supported with those of Sharma et al., (2012).

\section{Response of nutrients}

Among the nutrients, maximum response was noted with the application of NPK in rice $(15.9 \mathrm{~kg} / \mathrm{kg})$ and $\mathrm{N}$ in chickpea $(15.8 \mathrm{~kg} / \mathrm{kg})$ due to more yield improvement per $\mathrm{kg}$ of nutrient applied and more nutrient efficiency in that particular treatment (Table-5). Kumar et al., (2006) and Hiremath et al., (20 15) also recorded similar findings.

\section{Nutrient uptake}

Application of $\mathrm{NPK}+\mathrm{ZnSO}_{4}$ at recommended dose recorded significantly higher uptake of $\mathrm{N}, \mathrm{P}$ and $\mathrm{K}$ over rest of the treatments by both the crops. Similarly, total uptake of nutrients (NPK) by rice-chickpea cropping system was maximum $(409.9 \mathrm{~kg} / \mathrm{ha})$ under $\mathrm{NPK}+\mathrm{ZnSO}_{4}$ treatement. The increase in total uptake of nutrient due to application of $\mathrm{NPK}+\mathrm{ZnSO} 4$, NPK, NK, NP, N and farmer practice was $321.17,304.0,154.11,165.02,69.13$ and 165.63 per cent higher over control, respectively (Table-6). This could be attributed to the fact that added nutrient increased the $\mathrm{N}, \mathrm{P}$ and $\mathrm{K}$ concentrations in grain and straw/ stover of both the crops by providing balanced nutritional environment inside the plant and higher photosynthetic efficiency which favoured better growth and crop yield. Jain et al., (2012) also reported the similar findings.

The rate of increase in NPK uptake was drastically inferior under farmer's practice followed by application of NK nutrients over other nutrient combinations (Fig. 2).

\section{Soil fertility status}

The two year's pooled data on soil fertility status after harvest of the crops are presented in Table 6. The highest available nitrogen (271.57 kg/ha), phosphorus (19.14 kg/ha) and potassium $(353.94 \mathrm{~kg} / \mathrm{ha}$ ) were observed in $\mathrm{NPK}+\mathrm{ZnSO}_{4}$ treatment which was at par with the NPK application in recommended dose.

The inclusion of chickpea in the cropping system was responsible for improvement in the chemical properties of soil as chickpea being a legume add considerable amount nitrogen in soil through symbiotic $\mathrm{N}$ fixation. Significant improvement in post-harvest soil fertility in elevated doses of fertilizer was earlier reported by Hile et al., (2007), Jain et 
al., (2012) and Dechassa Hirpa Dibaba et al., (2014).

It may concluded that application of $100 \mathrm{~kg}$ $\mathrm{N}, 60 \mathrm{~kg} \mathrm{P} \mathrm{O}_{5}, 40 \mathrm{~kg} \mathrm{~K}_{2} \mathrm{O}$ and $20 \mathrm{~kg} \mathrm{ZnSO}_{4}$ to rice and $20 \mathrm{~kg} \mathrm{~N}, 50 \mathrm{~kg} \mathrm{P}_{2} \mathrm{O}_{5}$ and $20 \mathrm{~kg} \mathrm{~K}_{2} \mathrm{O}$ to chickpea could be recommended for improving the productivity and net returns from rice-chickpea cropping system.

\section{Acknowledgement}

The authors wish to acknowledge Dr. A.S. Panwar, Director, Dr. B. Gangwar, ExDirector, Dr. N. Ravisankar, Principal Scientist (Agronomy), PI, OFR Co-ordination Unit and Programme Facilitator (Coordination Unit) ICAR-Indian Institute of Farming System Research, Modipuram, Meerut, Dr. R.K. Dwivedi, Dean, SKCARS, Kawardha and Dr. M.C. Bhambri, Chief Agronomist, AICRP- IFS, Raipur for providing technical guidance and financial support to carry out this research work.

\section{References}

Dechassa Hirpa Dibaba, Hunshal, C.S., Hiremath, S.M., Awaknavar, J.S., Wali, M.C., Nadagouda, B.T. and Chandrashekar, C.P. 2014. Growth and yield of maize nybrias as iniiuencea oy application of NPK and S levels. Karnataka J. Agric. Sci., 27: 454-59.

Dhyani, B.P., Kumar, V., Dhahi, U.P., Vivek, Sharma, R.D. and Singh, S.P. 2007. Economics, Yield potential and soil health of rice-wheat cropping system under long term fertilizer experimentation. Indian $J$. Agric Sci., 77: 859-61.

Gangawar, P., Ravisankar, N., Vijayabaskaran, S. and Vishwanath, A.P. 2014. On-farm nutrient response of crops and cropping systems (compendium. All India Coordinated Research Project on Integrated Farming Systems, Project Directorate for Farming Systems Research, Modipuram, Meerut.

Gupta, B.R., Tiwari, T.P., Tiwari R. and Tiwari, K.N. 2007. Rebalancing nutrient application in late sown potato. Better Crops, 91: 10-12.

Hile, R.B., Patil, H.M., Patil, Y.J. and Bhosale, S.S. 2007. Effects of N, P and $\mathrm{K}$ on productivity and soil fertility in maizewheat cropping system. Int. J. Agric. Sci., 3: 205-07.

Hiremath, S.M. and Hosamani, M.H. 2015. Influence of balanced fertilization on productivity and nutrient use efficiency of maize (Zea mays)-chickpea (Cicer aritinum) cropping system. Res. on Crops, 16(3): 479-484

Jain, N.K., Hari Singh and Dashora, L.N. 2012. On-farm response of maize-wheat cropping system to fertilizer NPK input. Res. on Crops, 13: 475-80.

Kumar, A., Tripathi, H. P. and Kumar, S. 2006. Response of rice-wheat sequence to $\mathrm{N}, \mathrm{P}$ and $\mathrm{K}$ in Eastern Uttar Pradesh. J. Farming Systems Res. \& Dev., 12: 104-06.

Sharma, S.K., Jain, N.K. and Upadhyay, B. 2012. Effects of balanced fertilization on productivity and soil fertility status of maize. Res. on Crops, 13: 95-99.

Vidyavathi, Dasog, G.S., Babalad, H.B., Hebsur, N.S., Gali, S.K., Patil, S.G. and Alagawadi, A.R. 2011. Influence of nutrient management practice on crop response and economics in different cropping systems in a vertisol. Karnataka J. Agric. Sci., 24(4): 455-460.

\section{How to cite this article:}

Chandrakar, C.K., M.C. Bhambri, G.P. Pali, Sunil Kumar, A. Jangde, K.K. Pandey and Sanjeev Singh. 2017. Response of Plant Nutrients on Soil Fertility, Productivity and Profitability of Rice (Oryza sativa) -Chickpea (Cicer arietinum) Cropping System in Chhattisgarh Plains. Int.J.Curr.Microbiol.App.Sci. 6(4): 1867-1875. doi: https://doi.org/10.20546/ijcmas.2017.604.222 